\title{
Review
}

\section{Food Allergies: Immunosensors and Management}

\author{
Dyah Ika Krisnawati ${ }^{1, *}$, Moh Alimansur ${ }^{2}$, Didik Susetiyanto Atmojo ${ }^{1}$, Elfi Quyumi Rahmawati ${ }^{1}$, Dwi Rahayu ${ }^{1}$, \\ Erna Susilowati ${ }^{1}$ and Tsung-Rong Kuo ${ }^{3,4}$ (D)
}

1 Dharma Husada Nursing Academy, Kediri 64114, Indonesia; didik_atmojo@adhkediri.ac.id (D.S.A.); elfi_quyumi_r@adhkediri.ac.id (E.Q.R.); dwi_rahayu@adhkediri.ac.id (D.R.); erna_susilowati@adhkediri.ac.id (E.S.)

2 Faculty of Health Sciences, Kadiri University, Kediri 64115, Indonesia; ali.mansur75@unik-kediri.ac.id

3 Graduate Institute of Nanomedicine and Medical Engineering, College of Biomedical Engineering, Taipei Medical University, Taipei 11031, Taiwan; trkuo@tmu.edu.tw

4 International Ph.D. Program in Biomedical Engineering, College of Biomedical Engineering, Taipei Medical University, Taipei 11031, Taiwan

* Correspondence: dyahkrisna77@gmail.com

Citation: Krisnawati, D.I.; Alimansur, M.; Atmojo, D.S.; Rahmawati, E.Q.; Rahayu, D.; Susilowati, E.; Kuo, T.-R. Food Allergies: Immunosensors and Management. Appl. Sci. 2022, 12, 2393. https://doi.org/10.3390/ app12052393

Academic Editors: Kiril Tenekedjiev and Monica Gallo

Received: 7 January 2022

Accepted: 19 February 2022

Published: 25 February 2022

Publisher's Note: MDPI stays neutral with regard to jurisdictional claims in published maps and institutional affiliations.

Copyright: (C) 2022 by the authors. Licensee MDPI, Basel, Switzerland. This article is an open access article distributed under the terms and conditions of the Creative Commons Attribution (CC BY) license (https:// creativecommons.org/licenses/by/ $4.0 /)$.

\begin{abstract}
Food allergies (FA) are commonly depicted as immune responses. The mechanism of allergic reactions involves immunoglobulin E ( $\mathrm{IgE}$ ) and non-immunoglobulin E (non-IgE)-related responses caused by contact with specific foods. FAs can be fatal, have negative effects and have become the subject of fanaticism in recent years. In terms of food safety, allergic compounds have become a problem. The immune response to allergens is different to that from food intolerance, pharmacological reactions, and poisoning. The most important allergenic foods are soybeans, milk, eggs, groundnuts, shellfishes, tree nuts, cereals and fish, which together are known as the "Big Eight". This review will introduce and discuss FAs in milk, peanuts, nuts, shellfishes, eggs and wheat and their detections and potential treatments will also be provided. We believe that this review may provide important information regarding food-induced allergies for children who have allergic reactions and help them avoid the allergenic food in the future.
\end{abstract}

Keywords: food allergy; immuno-sensors; allergenic compound; immuno-treatment

\section{Introduction}

Food allergies (FA) are also depicted as immune responses. The mechanism of allergic responses contains IgE and non-IgE-related responses induced by contact with specific foods [1-6]. FAs can be fatal, can have negative effects and has become the subject of fanaticism in the last few years [7]. Many studies have demonstrated the issue of food allergies (FAs) in children, but FAs have no significant effect in adults [8,9]. About 10\% of the child population has been influenced by FAs [10]. In terms of food safety, allergic compounds have become a problem. The immune response to allergens is different from that of food intolerance, pharmacological response and poisoning. Based on a study published by the Food and Agriculture Organization of the United Nations (FAO), the most serious allergic foods are soybeans, milk, eggs, groundnuts, crustaceans, nuts, cereals, and fish, which together are known as the "Big Eight" [11-18]. Some foods offer no indication regarding the existence or absence of allergic compositions. Although food labels are important to offer consumers information about product ingredients, accidental exposure to certain allergenic compounds may occur. This exposure may be caused by undeclared allergens caused cross infection, illegal addition or even deception [19,20]. This review will summarize and discuss food allergy testing in milk, peanuts, wheat, nuts, shellfish and eggs (Figure 1). 


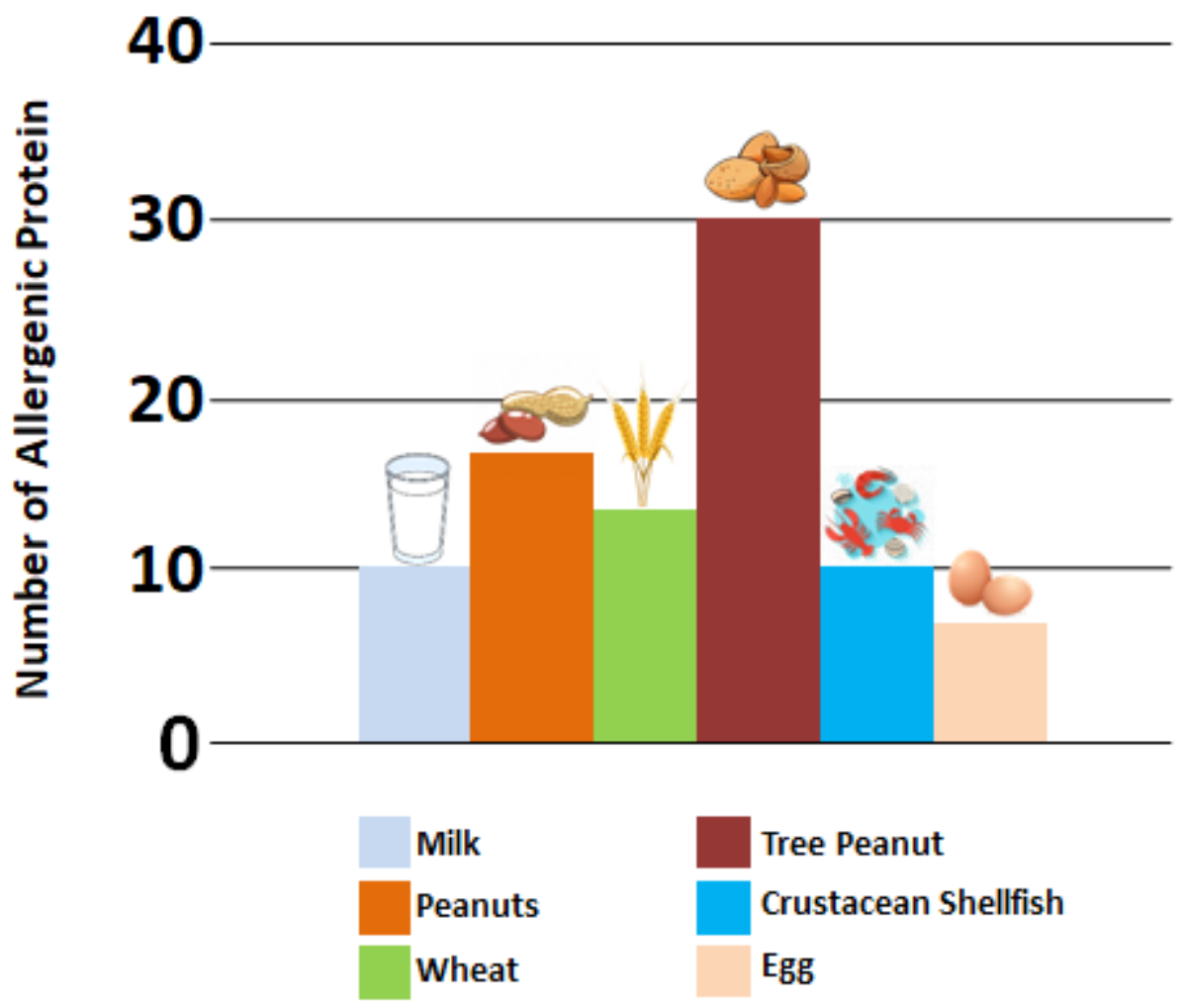

Figure 1. Illustration of various allergenic proteins contained in the major foods. This figure divides the sources of the major plant and animal.

\section{Milk Allergy}

Cow's milk allergy (CMA) is an ordinary type of FA which can last a lifetime [21]. Milk allergy is a top priority that needs attention for public health, especially in childhood. The reactions to FAs such as milk allergy are immune reactions to the constituents in food products, such as proteins, through the generation of IgE. The human body generates histamine, cytokines and other molecules which cause allergic symptoms including inflammation and severe reactions, such as fatal anaphylactic shock [22]. Problems that occur due to milk allergy are more serious because of cross-reactivity of milk allergens in food products coming from various species. This issue can be handled with suitable and trustworthy food labeling to ensure the quality of life of people with allergies. Therefore, it is necessary to use highly sensitive and accurate analytical instruments to measure the allergens of the foods.

\subsection{Standard Approaches for Analyses of Dairy Allergens}

The analytical approaches applied to detect milk allergens are protein-related and DNA-related. These approaches are based on the interactions between antigen and antibody including enzyme-linked immunosorbent assay (ELISA), dipstick assays, and lateral flow devices (LFD). Subsequently, polymerase chain reaction (PCR) and liquid-mass chromatography (LC-MS) tools are applied as alternative approaches for antibody-related methods. Immunology-related assays, including lateral flow-based assays (LFA) and ELISA are extensively utilized for detecting milk allergens with different commercial kits found in the market. LFA is a rapid and facile approach for measuring milk allergens and has been demonstrated to be inexpensive, but the possibilities for quantitative measurement by using this kind of method are currently limited. ELISA-based approaches, which apply antibodies for direct or sandwich methods, have been successfully demonstrated to detect a number of FAs. 


\subsection{Immunosensor}

Biosensors are an alternative offering comparable sensitivity and selectivity enabling on-line and real-time measurements. Great efforts have proven the use of biosensors in detecting milk protein. For example, Billakanti et al., have developed a biosensor based on the optical property of surface plasmon resonance (SPR) for the simultaneous measurements of various milk proteins in dairy goods showing different measurement scopes [22]. Recently, an SPR sensor was designed to detect the casein protein as a means for detecting allergens in laundry samples from the on-site cleaning system (CIP) of a food preparing process, providing an LOD of $58 \mathrm{ng} \mathrm{mL}^{-1}$ and adequate sampling. However, whey protein cannot be measured by the uses of casein-related sensors. Therefore, the fabrication of a lactoglobulin sensor is significant for the detection of whey protein allergens. Currently, there exists an immunoassay-based SPR sensor that is optimized to detect lactoglobulin for future application in on-site cleaning final rinse (CIP) water samples. SPR sensors have provided great advantages for these applications as they are fully automatic, flexible, fast, and real-time analyses. The sensors also offer the promise of on-line or at-line analysis to operate samples. Lactoglobulin is an essential milk protein and the measurement of lactoglobulin can be a reliable biomarker in the evaluation of milk content and milk whey fraction during the CIP process, in combination with with other acquainted allergen sampling methods such as surface swabs. Recent biosensors have sensitivities at sub-ppm levels, as well as superior selectivity, and are capable of measuring lactoglobulin at subppm concentrations. The SPR biosensors work alongside a casein sensor for simultaneous measurements of milk and whey fraction allergens when applied individually in the food manufacturing process [22]. These immunosensors have been investigated for the trustworthy measurement of IgG from unclean milk with colostrum or milk from various animals, including goat, cow, and sheep.

\subsection{Management}

In order to protect individuals who are sensitive to cow's milk allergens, a measurement approach, designed to have excellent sensitivity, high selectivity and superior accuracy is urgently needed. Currently, biosensors, including immunosensors and aptasensors, in combination with innovative nanomaterials and a detecting platform offer cheap, facile, fast, and multiple detection of dairy allergens compared with traditional approaches such as ELISA, LC-MS, and real-time PCR [23-30]. For this study, we reviewed many platforms with detectors using both immunosensors and aptasensors for milk allergens. Apart from the promise of immunosensors in the detection of milk allergens, other primary issues revolve around the instability and high cost of antibodies. Although the excellent and specific reactivity of aptamers has been applied to resolve the problem of detector cross-reactivity, the effect of the variability of allergens contained in different species on detection approaches needs to be examined. The development of aptasensors for detecting milk allergens is still in its early stages and still has a long distance to go to become an analytical tool with high stability. Current research on the design of innovative biosensors or biosensing platforms is critical in reducing the gap from research at lab scale to commercial products. The development of the biosensing platform and kit for the measurement of milk allergens is very important from the perspective of enforcing labeling regulations and directives with due regard for sensitive individuals. Therefore, the SPR biosensors for the detection of milk allergens have been utilized as a device to improve milk allergen safety in the industry. Furthermore, many works have been focused on utilizing a similar technology to develop antibody-related SPRs for the detection of other food allergens in food, including peanuts, eggs, etc. It is also of interest to evaluate the ability of the sensor for the detection of the absence of residual protein in CIP validation studies. Most importantly, from the literature, the concentration of milk proteins still needs to be standardized [22]. 


\section{Peanut Allergy}

Peanut allergy is a body reaction that occurs when a person eat nuts or peanut-based foods. Peanut allergens have a hidden negative impact on the health and quality of life of millions of consumers in the world. Individuals who have a predisposition to allergies are at risk of reactions when consuming peanuts, Arachis hypogaea peanuts contain a series of allergens that can cause the generation of specific IgE antibodies [31]. Peanuts are one type of food that is good for consumption, because they contain complete nutrients, such as protein, carbohydrates, fats, vitamins, and minerals [32]. Beans are also a general food that induce serious FAs and are one of the "top eight FAs", with a worldwide prevalence of $0.5-2 \%$, and steadily increasing [33]. The number of reported cases of peanut allergy in children continues to increase. The prevalence of peanut allergy has increased by $21 \%$ since 2010 in the United States and is expected to continuously increase [34]. Allergy caused by plant-based foods is a highly complicated disorder with clinical features including mild oral, gastrointestinal, and skin symptoms and can result in fatal conditions. Heterogeneity in clinical characteristic has been ascribed to the various nature of the allergenic chemicals [35].

\subsection{Immunosensor}

Food hypersensitivities are serious resistant reactions, interceded by immunoglobulin E (IgE), to explicit food sources [35]. More than half of the plant allergens, including peanut allergens, have a place within four classifications of protein, including the prolamin superfamily, cupin superfamily, profilins, and Bet v-1-related proteins. The nut species of Arachis hypogaea accounts for 17 allergens with Ara $\mathrm{h}$ 4, which has been renamed Ara $h 3.02$, accounting for an overall number of 16 of the perceived allergens in nut seeds (Allergen Nomenclature Sub-Committee of the World Health Organization/International Union of immunological Societies, WHO/IUIS) [36]. Ara h 2 and Ara h 6 (prolamin classification, 2S egg whites family) and Ara h 1 and Ara h 3 (cupin classification) are viewed as significant allergens in peanuts, affecting $>50 \%$ of allergenic individuals. Ara $\mathrm{h} 2$ is viewed as the most powerful allergen protein because it is demonstrated by serum $\operatorname{IgE}$ tp affect over $90 \%$ of nut-allergenic patients. Ara h 6 offers comparative immunological highlights alongside Ara h 2, something that was demonstrated when as it was noticed that eliminating Ara h 2 and Ara h 6 allergen proteins together led to an overall decrease in the effector action of the nut seeds' rough protein extricate, highlighting the purposes behind our decision to examine these two homologs in this study. Further, this underlines the attractiveness of these homologs in restorative applications $[37,38]$. Until this point in time, the WHO/IUIS Allergen Nomenclature Sub-Committee (http: / / www.allergen.org, accessed on 20 April 2021), the solitary assortment of specialists approved to appoint official allergen assignments, perceives 16 nut allergens.

\subsection{Management}

The solvency of nut protein is influenced by warm handling techniques and preparation times. The water-solvent protein yield of crude peanuts was $72 \%$ of complete protein. In any case, the dissolvability of the protein was diminished alongside expanded handling time. Fricasseeing for $8 \mathrm{~min}$ resulted in the least water-solvent protein yield of $6.4 \%$ of the overall protein (dry premise), which diminished $66.5 \%$ of the dissolvability. The allergen's quantitative assurance depended on the band forces and favorability to tein substance. The nut preparation impacts water-solvent protein (allergen). Water-solvent Ara h 1, Ara h 2 and Ara $\mathrm{h} 3$ substance, estimated by the strategy of Bradford (1976) for crude peanuts, are 3.2, 1.9, and 9.5 g/100 g nut (dry premise), respectively. Bubbling, HP bubbling, Steaming, $\mathrm{HP}$ steaming, and profound browning all diminished the water-dissolvable Ara $\mathrm{h} 1$ and Ara $\mathrm{h} 2$ substances to almost zero (under $0.1 \mathrm{~g} / 100 \mathrm{~g}$ nut for Ara $\mathrm{h} 1$ and under $0.2 \mathrm{~g} / 100 \mathrm{~g}$ nut for Ara $h$ 2) before the cooking was complete. These discoveries were predicted by a new investigation by Comstock, Maleki, and Teuber (2016), in which they found that bubbling and searing could diminish the solvency of Ara $\mathrm{h} 1$ and Ara $\mathrm{h} 2$ because of the compliance changes [35]. 
One way to decrease the nut sensitivity reaction is to remove the allergens in peanuts; expulsion of the allergens of Ara h 2 and Ara $\mathrm{h} 6$ from a concentrate brings about a deficiency of their strength [39]. Peanuts go through warm preparation before utilization. They are eaten bubbled, singed, or cooked by different culinary practices. These preparation techniques appear to affect the pervasiveness of nut sensitivity. Allergenicity of nut proteins is additionally influenced by primary changes prompted by warm handling. Browning of peanuts, yet not bubbling or cooking, changed the optional design of Ara h 2 drastically by diminishing the particle's substance of $\alpha$-helices and expanding its $\beta$-sheets, $\beta$-turn and arbitrary loop, in this manner modifying Ara h 2 epitopes and decreasing its allergenicity [40].

\section{Tree Nut Allergy}

Peanuts are considered part of a healthy diet (they are, for example, high in lipids and essential amino acids (aa), and rich in minerals such as potassium, magnesium, and calcium) and eaten as a single food or as a component of multiple ingredients. These foods are added to dishes in different densities [41-43]. However, plant-derived foods account for approximately $90 \%$ of FA cases [44-46]. The prevalence of cashew nut allergy is increasing, with clinical features ranging from oral itching to fatal allergic reactions $[47,48]$. Allergies to peanuts and nuts are usually permanent and usually life-threatening. They are caused by a small number of allergens that account for the majority of food allergies in adults [49]. It has been reported that the frequency of walnut allergy in children with IgEmediated food allergy is 4.2\% [50]. A survey conducted between 2015 and 2016 estimates that the prevalence of peanut allergy among children in the United States was $2.5 \%$, and Weinberger and Sicherer have reported that the prevalence of tree nuts was between $0.05 \%$ and $7.3 \%$ [51]. Cashew nut allergy is the second-most common tree nut allergy (affecting $20 \%$ of tree nut allergy subjects) [52].

\subsection{Immunosensor}

Allergic reactions to peanuts is caused by the body rejecting incoming allergens. The allergen becomes a foreign body in the patient's body, so the patient's body produces defense systems (antibodies) to attack it. Upon initial contact, food allergens are recognized by antigen-presenting cells and expressed on $\mathrm{T}$ cells directly or through cytokinins. $\mathrm{T}$ cells are sensitized and stimulate B cells to produce antibodies of various subtypes. The incoming allergens will be fully absorbed by the intestine and reach the antibody-forming cells in the intestinal mucosa and intestinal lymphatic organs [53]. Six allergenic proteins have been discovered in walnuts: Jug r 1 (2S albumin), Jug r 2 (vicilin), Jug r 3 (nonspecific lipid transfer protein), Jug r 4 (11S globulin), Jug r 5 (Bet v 1-homolog) and Jug r 7 (profilin) [54]. Jug $r 2$ has been proven by Teuber et al. to be the main allergen in the standard walnut (Juglans regia), it has been studied using recombinant (r)Jug r 2. Jug r 6, is a plentiful allergenic pea protein contained in walnut kernels. This vicilin is found in walnut kernels and can be acquainted to IgE antibodies in the serum of allergic patients. IgE has a mast cell sensitization effect in the gastrointestinal tract, respiratory tract, skin and other organs. Intestinal epithelial cells play an important role in determining the rate and pattern of antigen uptake. Foreign bodies dissolved in the intestinal lumen are absorbed by gastrointestinal epithelial cells, resulting in suppression of the immune system (tolerance). Ingestion of dietary protein usually activates $\mathrm{TCD}^{8+}$ suppressor cells located in the lymphatic tissues of the intestine. These cells are located in the spleen.

\subsection{Management}

Refined vicilins (rJug r 2 and nCor a 11), filbert, pistachio, and sesame extracts have been applied to block the binding of specific IgE from walnut allergic patients' sera to natural Jug r 6 . Moreover, the opposite inhibition with pre-incubation of Jug r 6 and detection of IgE against Jug $r 2$ has been developed [54]. The presence of the correlation 
of T-cell epitopes has increased the likelihood that single-species peptide immunotherapy could be effective in modulating.

\section{Shellfish Allergy}

Shellfish allergy influences about $2 \%$ of the global population and continues for life in most patients [54]. The detection of shellfish allergies, particularly for shrimp, is still an urgent issue because of the resemblance of allergen proteins from other invertebrates [55]. The prevalence of FAs has increased continuously in recent years and around $10 \%$ of children have various types of FAs. For sensitized persons, the generation of specific IgE antibodies from activated B cells of the immune system has been induced by exposure to shellfish allergens via ingestion or inhalation. These IgE antibodies further conjugate with immune effector cells such as mast cells and basophils to result in degranulation and clinical features of allergic symptoms [48]. Reactions to shrimp allergens are induced by different routes including the inhalation of shrimp particles, and so on. Symptoms of allergy to shrimp affect a number of organs, including skin (52-90\%), respiratory tract (42\%), digestive tract (35\%), and cardiovascular system (10\% anaphylaxis) [46]. Two allergens of the muscle protein, tropomyosin (TM) and the enzyme arginine kinase (AK), are the most important for shellfish allergies. Furthermore, tropomyosin is a major allergen in shellfish and contains a specific IgE antibody, one that accounts for the responses of about $60-80 \%$ of shellfish allergy patients and has also been demonstrated to be a good biomarker for serious clinical reaction to shellfish [56]. With the high prevalence of fish and shellfish allergies, the development of appropriate theranostic protocols is necessary to provide appropriate prevention and management strategies to eliminating unnecessary dietary confinements. Traditional clinical diagnostic approaches include clinical evaluation, oral food challenge (open or closed), skin prick test (SPT), and serum-specific IgE (sIgE) detection [57].

\subsection{Immunosensor}

Clinical cross-interaction in different fish materials is ordinary even in fish of taxonomically different orders. Sensitization to allergens and their peptides varies among patients due to geographic or ethnic differences [58]. The clam group includes crustaceans (the arthropod phylum includes shrimp, lobster and crab) and mollusks (the mollusk phylum includes oysters, mussels and squid) [59]. Many shellfish allergens have been investigated based on patient serum IgE reactivity. The main shrimp allergen, tropomyosin, has been demonstrated to cause CD4+ T cell proliferation in allergic materials and some $\mathrm{T}$ cell epitopes of tropomyosin and shrimp arginine kinase have been identified. The rationale for specific treatment designs requires an explanation of the factors that influence the development of a Th2 polarized response to shellfish allergens. Allergens are absorbed by antigen-presenting cells (APCs) on mucosal surfaces and then progressed and revealed as peptides complexed with MHCc [60]. For individual allergens, allergen-stimulated T cells generate IL-4, IL-5 and IL-13, Th2-type cytokines to induce and propagate allergic IgE-mediated immune responses. Mast cells and basophils are activated by allergen crosslinking of IgE-specific surface-bound cells for the release of a cascade of inflammatory mediators, resulting in the clinical features of FA. Intersect-reactivity has been generated by IgE antibodies with the same, or very similar, proteins of epitopes in comparison with the primary sensing protein. These epitopes have been explored with the aim of developing novel predictive diagnostic instruments for shellfish allergy patients [56].

\subsection{Management}

Precise diagnosis of FAs is very important for the selection of suitable treatment. Currently, the best recommended treatment of FAs is to avoid eating the allergenic foods. Nowadays, some primary allergens in shellfish have been discovered, including tropomyosin, arginine kinase, myosin light chain, sarcoplasmic calcium-binding protein, hemocyanin, troponin-C, myosin heavy chain, glyceraldehyde phosphate dehydrogenase, and ubiquitin. Elimination of the mollusk species of shellfish in the patient's diet is one alternative man- 
agement approach for shrimp-allergic patients [56]. A decision tree has been developed to examine the promising cross-reactivity of shrimp mollusks in shrimp-allergic patients in order to conserve types of shrimp IgE-binding epitopes TM and AK in mollusk species. A patient's clinical history does not provide an exact conclusion in the detection of shrimp allergy. Sensitization assays to whole shrimp and specific allergens are required before an oral food challenge is undertaken. If the TM-specific IgE result is positive, with quantitative IgE levels with TM similar to the whole protein extract, immune dominant sensitization to mussel TM is possible, and broad (serological) cross-reactivity against other shellfish species should be performed. Analyzing the binding of IgE to the shrimp TM epitope can further assist the diagnosis of cross-reactivity. Inhalation during commercial processing may cause sensitization to seafood. Identification of food handling as the cause of adverse reactions is a route that is indistinguishable in all subjects and general reports of ingestion-related allergic information. The extractions of cooked foods have more IgE activity than raw foods, which may be attributed to general consumption of crab, shrimp or chemical modification of crustacean proteins on heating. The activity of $\operatorname{IgE}$ in clinically relevant crustacean extracts have been proven by functional basophil activation assay. The relative reactivity of crustacean species is very important to understand so that subjects who are allergic to shellfish receive the best clinical treatment on food avoidance [59]. Food processing can affect the identification of FAs by immune cells and the following allergic immune response. Food cooking can change the composition of the allergen because of protein denaturation, aggregation and chemical modification. These changes of molecular structure may result in the involvement of allergens with various receptors for immune cells [60]. Proliferation and effector cytokine profiles (IFN- $\gamma$, IL-4) of CD4+, CD8+ and CD56+ cells, and the proportion of Foxp3+ Tregs have been compared. Detection of cellular responses to these processed crustacean allergens has informed the progress of safe and effective specific immunotherapies. Crustacean-allergic and non-atopic subjects have revealed similar lymphocyte proliferative responses to crustacean extracts but with a greater response to crude extracts. There is a tendency to decrease the proliferation of PBMCs in reply to cooked crustacean extracts. Treg induction is also decreased.

\section{Egg Allergy}

Hypersensitivity to Gallus (chicken) eggs is a widespread disease that usually affects up to $9 \%$ of children worldwide [61,62]. According to records, it is one of the most common food allergies among children [63]. A 2016 study indicated by the Beating Egg Allergy Trial (BEAT) found that egg allergy is the main factor of IgE-related FAs in Australian children. This is also examined by the Health Nut study. The cohort study has found that in comparison with other major FAs such as peanuts (3.1\%) and milk $(1.5 \%)$, the prevalence of egg allergy in one-year-old babies is $9.5 \%$ [64,65]. Spontaneous resolution and tolerance of egg allergies are common, occurring for $60-75 \%$ of adolescents; however, the disease is burdened in early childhood due to symptoms including vomiting, abdominal pain, diarrhea, and urticaria [66,67]. Although egg allergy is believed to be a disease for children, there are still some allergic children who continue to experience egg allergy as adults, which further raises the hazard of latently fatal reactions [56]. Egg allergy starts when the body over-reacts to the protein in egg white and yolk. The four main proteins in egg whites are the primary triggers for egg allergies because many studies have proven that few egg yolk proteins are allergenic (Figure 2) [68]. In 2019, Dang and colleagues demonstrated that most infants with egg allergies are sensitive to egg white allergens but not to egg yolks. 


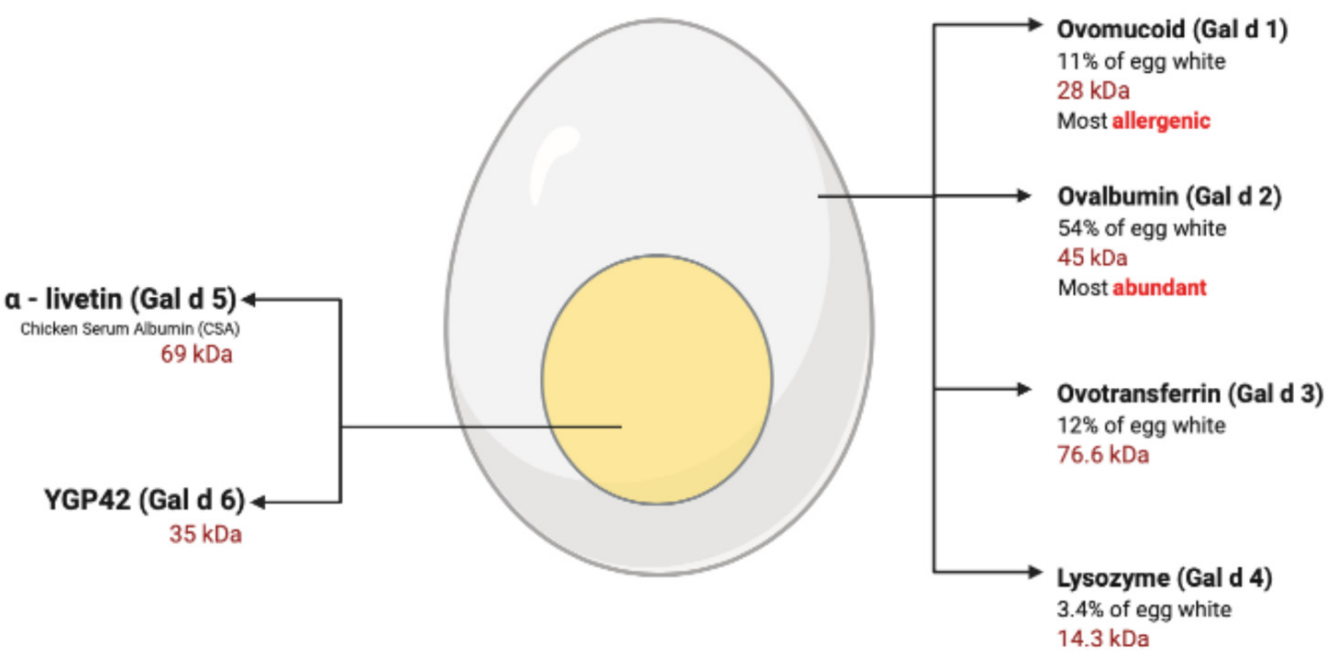

Figure 2. Egg allergens, notice the six significant egg allergens with a portion of their physicochemical properties [68].

Thusly, allergens inside the egg white have been broadly examined, while egg yolk allergens have gotten next to no consideration, something which underlines the requirement for the comprehensive examination of all significant egg allergens [69]. The standard way to deal with egg sensitivity currently is through severe evasion. This, however, is unfeasible because of the utilization of eggs in a broad scope of prepared food varieties and drug products, including immunizations [70]. Besides, evasion of all egg items represents a significant detriment as eggs are of high dietetic importance, giving fundamental nutrients, proteins and unsaturated fats [71]. Contrastingly, research shows that the capacity to endure cooked egg provides an expected indicator of temporary egg sensitivity, with $80 \%$ of children with a crude egg hypersensitivity able to endure the consumption of cooked types of egg [72,73]. This is essential to think about given the current administration for egg sensitivities, featuring the further requirement for precise analysis, anticipation and discrimination between egg-hypersensitivity, egg open minded and egg-sharpened people. Exploration led by the Beating Egg Allergy Trial (BEAT) in 2016 discovered egg hypersensitivity to be the main source of IgE-intervened food sensitivities in Australian children. This was likewise affirmed by The HealthNut study which discovered that the predominance of egg sensitivity at one year old to be $9.5 \%$ when contrasted with other significant food hypersensitivities, such as nut $(3.1 \%)$ and cow's milk $(1.5 \%)[64,65]$. Unconstrained resistance to egg sensitivity is normal and happens in $60-75 \%$ of youngsters preceding their adolescent years; however, the weight of the infection is serious during youth as side effects incorporate vomiting, stomach pain, loose bowels and urticaria [66,67]. While egg sensitivity is viewed as a youth infection, an amount of unfavorably susceptible youngsters continue to encounter tenacious egg hypersensitivities into adulthood, further expanding the danger of a conceivably lethal reaction [64].

\subsection{Immunosensor}

A hypersensitive response or reaction incorporates two particular stages dependent on the exposure of the allergen with the resistant framework, alluded to as the humoral or essential reaction and the cell-interceded or auxiliary reaction [74]. The first contact with an allergen animates the humoral reaction as the allergen is inundated and prepared by the APC, introducing them to CD4+ guileless T-aide cells (Th0). The enactment of APC permits T-cell development according to thymic stromal lymphopoietin (TSLP). Due to the co-stimulatory molecules communicated by the APC, Th0 cells are prepared and separated into T-aide type 2 cells (Th2) within the sight of cytokines, for example interleukin-4 (IL-4), interleukin-25 (IL-25), interleukin-10 (IL-10) and interleukin-18 (IL-18) [75]. Th2 cells advance the emission of IL-4, IL-5 and interleukin-13 (IL-13). This, thusly, instigates B-cells to go through immunizer 
class exchanging (separation) from immunoglobulin M (IgM) neutralizer to plasma cells discharging allergen-explicit IgE to the uncovered allergen (Figure 3) [76].

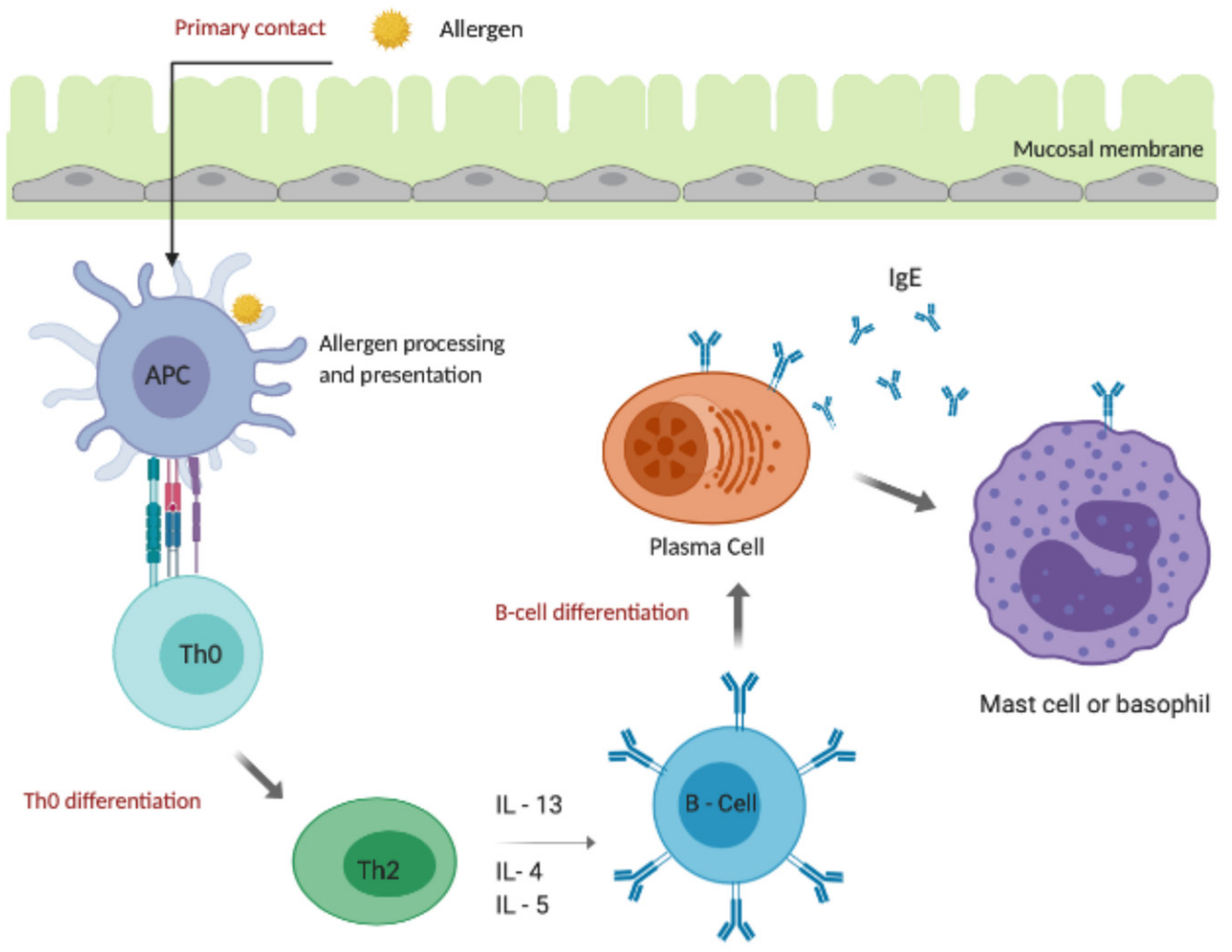

Figure 3. Outline of the humoral hypersensitive reaction. This figure traces the routes of the humoral reaction. When the allergen is handled and introduced by the APC's to the Th0 cells, the Th0 cells differentiate into Th2 cells in hypersensitive people. Th2 discharges IL-4, IL-5 and IL-13, setting off B-cell differentiation into plasma cells. Accordingly, they multiply and produce unreasonable sums of allergen-explicit IgE that bind to Fc"RI receptors on pole cells and basophils. This interaction is said to sensitize the resistant framework. Optional and ensuing openness to a similar allergen prompts cross-connection at the $\mathrm{Fc}^{\prime \prime} \mathrm{RI}$ receptors, setting off the arrival of go-betweens such as histamine, causing an unfavorably susceptible irritation.

The arrival of IL- 5 by Th2 animates and enacts the creation of eosinophils. Thus, allergen-explicit IgE antibodies bind to the high-proclivity FceRI receptors on pole cells and basophils, which are the effector cells of hypersensitivities, sharpening the safe framework to the allergen [77]. The impacts of these cells are alluded to as the "beginning stage response", which happens promptly after optional openness [78]. The essential reaction to food allergens likewise includes antibodies of the isotypes immunoglobulin A (IgA) and immunoglobulin $\mathrm{G}(\operatorname{IgG})$, with each varying in capacity and reaction relying upon the dietary allergen [79]. IgG is a commonly recognized counter acting agent, which is verified in blood and other natural liquids and fights bacterial and viral contaminations. However, the inclusion of IgG as an indicator system of food allergen-prompted hypersensitive response is as yet under investigation. In 2020, the WAO expressed that "more examinations are expected to characterize explicit IgG as a biomarker of food hypersensitivity" [80].

\subsection{Management}

As of now, there is no transitory or lasting remedy for hypersensitivities. When a finding affirms a hypersensitivity, specifically an egg sensitivity, the current treatment includes severe dietary aversion or limited touch with the allergen [81]. Pharmacotherapies are utilized to kill the side effects by hindering hypersensitive arbiters (e.g., antihistamines) however these are not therapeutic as they can't repress IgE creation. Besides, adversar- 
ial drugs, such as histamine rivals, against leukotrienes, pole cell stabilizer blockers and corticosteroids to decrease aggravation, can animate immunosuppression [82,83]. Dangerous hypersensitivity is accounted for between $30-50 \%$ of all food-initiated sensitivity cases in Australia, Asia, Europe and North America, as such epinephrine is frequently controlled during serious responses to forestall anaphylactic shock $[84,85]$. Food-instigated hypersensitivity, especially in children, happens because of egg and milk sensitivities; while uncommon, deadly responses have been accounted for in the United Kingdom. Immunotherapy is viewed as the most efficient approach to treat and alleviate the side effects of hypersensitivities, with clinical investigations demonstrating that immunotherapy approaches can possibly improve unfavorably susceptible manifestations as well as to ultimately forestall sensitivities [86,87]. The cycle includes the customary organization of allergen concentrates to achieve quantifiable resilience to the symptom-creating allergens in patients with a perceivable hypersensitive sickness $[88,89]$. The primary rule of treatment is regularly alluded to as desensitization, where clinical effectiveness is portion subordinate.

\section{Wheat Allergy}

Wheat is the most common component in our daily food. Wheat contains many important dietary compositions, including carbohydrates, fats, cellulose, minerals, proteins, vitamins and water [90]. Wheat belongs to the major allergy-eliciting foods inducing local features and serious systemic responses [91]. In the population of children with a wheat FA, more than $50 \%$ have experienced anaphylaxis upon wheat absorption. Wheat has been demonstrated to be one of the main origins of food allergens involved in food-induced anaphylaxis, in a study of 1000 patients with FA [92]. Wheat is an important staple cereal grain consumed globally, and is an excellent source of nutrition for humans. In fact, for a small part of the population, some wheat compositions, especially proteins, are correlated with some important medical diseases that have affected patient health and quality of life and can even be fatal.

The big three cereal crops of wheat, maize and rice have been cultivated globally because of their adaptability, nutritional value, and versatility. This is due to their superior viscoelastic characteristics and capability to increase a wide range of products, including bread, pasta, noodles, and biscuits. FAs are serious issues for global public health. However, the exposure to low concentrations of an allergen has provoked a critical response in allergic persons, and the only valid way to avoid allergy is to avoid food items that have been made using such allergens. A latter European Directive concerning food safety (No. 1169/2011) has listed 14 major allergenic food compositions. Food companies and factories have a responsibility to examine the allergic compositions and announce them on a safety label for their products [90]. It is important to emphasize that unintentional cross-contamination can occur between various food compositions and allergens in raw materials, reworked products, or due to contact with allergens travelling through the use of shared tools or production plants. Furthermore, to avoid cross-contamination of allergenic materials in food goods, many food companies have focused on very strict allergen-control detections, including the use of dedicated instruments and production systems.

\subsection{Immunosensor}

For patients with wheat FAs, the proteins and peptides with $\operatorname{IgE}$ reactivity have been investigated in non-denaturing RAST-based binding analyses. For a soluble and monomeric protein, alpha-purothionin is expressed in the prokaryotic (EcTri a 37) and the eukaryotic system (BvTri a 37). However, circular dichroism assay has demonstrated that EcTri a 37 has an unfolded protein and BvTri a 37 has a folded protein. These two proteins show comparable IgE-reactivity and the epitope mapping shows the existence of sequential $\operatorname{IgE}$ epitopes in the $\mathrm{N}$-terminal basic thionin domain (peptide1) and in the C-terminal acidic extension domain (peptide3 and peptide4). Wheat has given rise to abnormal reactions, although the inducing factors have not been determined so far. These reactions are primarily induced by kernel proteins, including both gluten and non-gluten proteins. Among these non-gluten proteins, 
$\alpha$-amylase/trypsin inhibitors (ATI) have been included in baker's asthma and in Non-Celiac Wheat Sensitivity (NCWS). The characterizations of three transgenic lines have been obtained from the bread wheat cultivar Bobwhite silenced by RNAi in the three ATI genes, including CM3, CM16 and 0.28 .

Responses to allergy are displayed in different ways, according to the pathways of exposure, i.e., ingestion (FA, either IgE-related or non-IgE-related), respiratory (baker's asthma), and skin contact (contact urticaria). The affronting allergens encompass the gliadins, glutenins, and other non-gluten proteins. FA of wheat is typically IgE-related, influences around $\sim 0.5 \%$ of children and mostly resolves by adulthood [93]. Symptoms are classically severe after the ingestion of wheat for several minutes and increase the risk of fatal anaphylactic response. Some rare non-IgE-related gastrointestinal situations combined with ingestion of wheat hypersensitivity have also been studied and showed eosinophilic esophagitis and food protein-induced enterocolitis syndrome. However, the proteins of wheat correlated with these dysfunctions have not been clearly identified [94]. Wheat flour (Triticum aestivum) has opportunities to be contaminated by different routes according to the Brassicaceae or during grain harvests, storage, and processing. In many cases mustards, such as Brassica nigra, Brassica juncea and Sinapis alba, are most common allergenic species. Usually, in laboratories, the assays of food quality have adopted an ELISA approach to examine the presence of mustard species and this approach has shown cross-reactivity with other non-allergenic species of Brassica napus.

\subsection{Management}

The reactivity of Tri a 37 does not require a folded protein and the existence of sequential IgE epitopes indicates that sensitization to alpha-purothionin occurs through the gut. In-vitro analysis has been applied for the allergens affecting FA of wheat. The induction of blocking IgG antibodies has indicated the effectiveness for immunotherapy. The advance of novel genotypes congesting a smaller amount of proteins potentially or effectively contained in allergies to wheat and NCWS has offered the potential to utilize them as a standard for the amelioration of the effects of harmful reactions, and for use as an assay for those proteins that are very complicated in pathologies for which the inducing factor has not been found yet [95]. DNA of matK, ITS2 and chromosome biomarkers, including the A6, B, C1 genome regions have been chosen and the specific primers have been identified on food matrices. The assay has demonstrated the capability to differentiate mustard from rapeseed and wheat, overcoming cross-reactivity with Brassica napus. The disease of RefSeq v1.0 Celiac and WDEIA genes are basically shown in the starchy endosperm and revealed in a wide differentiation in protein- and transcript-level expression for the reaction to temperature stress. Proteins with non-specific lipid change and amylase trypsin inhibitor gene families have correlated with baker's asthma. These proteins are primarily exhibited in the aleurone layer and transfer cells of grains and become sensitive in cold temperatures. The treatment often contains a daily dietary regimen with exclusion of wheat and other food proteins.

\section{Conclusions}

FA is often described as an immune response, which is a special challenge that requires special attention to prevention and treatment. For the treatment during allergic events, mild allergies can be relieved by taking antihistamines, and severe allergic reactions should be treated immediately with oral steroids or injections of epinephrine. There are still many people who do not know the importance of understanding the early symptoms and treatment of food-induced allergies. In principle, the handling of food allergies is the

same. Correct diagnosis of food allergies is very important for proper treatment. Currently, avoiding the food that causes the allergy is the best recommended treatment. Identification of food handling as the cause of adverse reactions, is a route that is indistinguishable in all subjects and reported as the main origin of ingestion-related allergic episodes. Food processing can affect the recognition of food allergens by immune cells and the subsequent 
immune response. Cooking can alter the structure of allergens through protein denaturation, aggregation and chemical modification. This review discussed the incidence of allergies caused by the six main ingredients of food: milk, peanuts, wheat, nuts, shellfish, and eggs. It also discussed the immune response and its treatment during allergic events. We believe that this review can improve the understanding of FAs. It is important to know that there are other ways to prevent food-induced allergies, such as testing for allergens in childhood to prevent them from developing allergies in the future.

Author Contributions: Conceptualization, D.I.K., M.A., D.S.A., E.Q.R., D.R., E.S. and T.-R.K.; writing-original draft preparation, D.I.K. and T.-R.K.; writing-review and editing, D.I.K. and T.-R.K.; supervision, D.I.K.; project administration, D.I.K. and T.-R.K.; funding acquisition, D.I.K. and T.-R.K. All authors have read and agreed to the published version of the manuscript.

Funding: This work was supported by Ministry of Science and Technology Taiwan (MOST 109-2113M-038-005-MY2), Taipei Medical University and Dharma Husada Nursing Academy, Kediri, East Java, Indonesia.

Institutional Review Board Statement: Not applicable.

Informed Consent Statement: Not applicable.

Data Availability Statement: Not applicable.

Conflicts of Interest: The authors declare no conflict of interest.

\section{References}

1. Ross, G.M.S.; Bremer, M.G.E.G.; Nielen, M.W.F. Consumer-friendly food allergen detection: Moving towards smartphone-based immunoassays. Anal. Bioanal. Chem. 2018, 410, 5353-5371. [CrossRef] [PubMed]

2. Ashley, J.; Shukor, Y.; D’Aurelio, R.; Trinh, L.; Rodgers, T.L.; Temblay, J.; Pleasants, M.; Tothill, I.E. Synthesis of Molecularly Imprinted Polymer Nanoparticles for $\alpha$-Casein Detection Using Surface Plasmon Resonance as a Milk Allergen Sensor. ACS Sens. 2018, 3, 418-424. [CrossRef] [PubMed]

3. Prado, M.; Ortea, I.; Vial, S.; Rivas, J.; Calo-Mata, P.; Barros-Velázquez, J. Advanced DNA- and Protein-Based Methods for the Detection and Investigation of Food Allergens. Crit. Rev. Food Sci. Nutr. 2016, 56, 2511-2542. [CrossRef]

4. Yuan, D.; Fang, X.; Liu, Y.; Kong, J.; Chen, Q. A hybridization chain reaction coupled with gold nanoparticles for allergen gene detection in peanut, soybean and sesame DNAs. Analyst 2019, 144, 3886-3891. [CrossRef]

5. Boushell, V.; Pang, S.; He, L. Aptamer-Based SERS Detection of Lysozyme on a Food-Handling Surface. J. Food Sci. 2017, 82, 225-231. [CrossRef]

6. Zhou, J.; Wang, Y.; Qian, Y.; Zhang, T.; Zheng, L.; Fu, L. Quantification of shellfish major allergen tropomyosin by SPR biosensor with gold patterned Biochips. Food Control 2020, 107, 106547. [CrossRef]

7. Jiang, H.; Jiang, D.; Zhu, P.; Pi, F.; Ji, J.; Sun, C.; Sun, J.; Sun, X. A novel mast cell co-culture microfluidic chip for the electrochemical evaluation of food allergen. Biosens. Bioelectron. 2016, 83, 126-133. [CrossRef] [PubMed]

8. Gupta, R.S.; Warren, C.M.; Smith, B.M.; Jiang, J.; Blumenstock, J.A.; Davis, M.M.; Schleimer, R.P.; Nadeau, K.C. Prevalence and Severity of Food Allergies Among US Adults. JAMA Netw. Open 2019, 2, e185630. [CrossRef]

9. Gómez-Arribas, L.N.; Benito-Peña, E.; Hurtado-Sánchez, M.d.C.; Moreno-Bondi, M.C. Biosensing based on nanoparticles for food allergens detection. Sensors 2018, 18, 1087. [CrossRef]

10. Alves, R.C.; Barroso, M.F.; González-García, M.B.; Oliveira, M.B.P.P.; Delerue-Matos, C. New Trends in Food Allergens Detection: Toward Biosensing Strategies. Crit. Rev. Food Sci. Nutr. 2016, 56, 2304-2319. [CrossRef] [PubMed]

11. Wang, W.; Han, J.; Wu, Y.; Yuan, F.; Chen, Y.; Ge, Y. Simultaneous detection of eight food allergens using optical thin-film biosensor chips. J. Agric. Food Chem. 2011, 59, 6889-6894. [CrossRef]

12. Gupta, R.S.; Warrier, M.R.; Springston, E.E.; Smith, B.M. The Prevalence of Childhood Food Allergy in the United States. J. Allergy Clin. Immunol. 2011, 127, AB33. [CrossRef]

13. Chafen, J.J.S.; Newberry, S.J.; Riedl, M.A.; Bravata, D.M.; Maglione, M.; Suttorp, M.J.; Sundaram, V.; Paig, N.M.; Towfigh, A.; Hulley, B.J.; et al. Diagnosing and Managing Common Food Allergies A Systematic Review. JAMA 2015, 303, 1848-1856. [CrossRef] [PubMed]

14. Badran, A.A.; Morais, S.; Maquieira, Á. Simultaneous determination of four food allergens using compact disc immunoassaying technology. Anal. Bioanal. Chem. 2017, 409, 2261-2268. [CrossRef]

15. Pilolli, R.; Monaci, L.; Visconti, A. Advances in biosensor development based on integrating nanotechnology and applied to food-allergen management. TrAC Trends Anal. Chem. 2013, 47, 12-26. [CrossRef]

16. Nurmatov, U.; Venderbosch, I.; Devereux, G.; Simon, F.E.R.; Sheikh, A. Allergen-specific oral immunotherapy for peanut allergy. Cochrane Database Syst. Rev. 2012, 9, CD009014. [CrossRef] 
17. Sobhan, A.; Oh, J.H.; Park, M.K.; Kim, S.W.; Park, C.; Lee, J. Assessment of peanut allergen Ara h1 in processed foods using a SWCNTs-based nanobiosensor. Biosci. Biotechnol. Biochem. 2018, 82, 1134-1142. [CrossRef] [PubMed]

18. Jiang, D.; Ji, J.; An, L.; Sun, X.; Zhang, Y.; Zhang, G.; Tang, L. Mast cell-based electrochemical biosensor for quantification of the major shrimp allergen Pen a 1 (tropomyosin). Biosens. Bioelectron. 2013, 50, 150-156. [CrossRef] [PubMed]

19. Campuzano, S.; Montiel, V.R.V.; Serafín, V.; Yáñez-Sedeño, P.; Pingarrón, J.M. Cutting-Edge Advances in Electrochemical Affinity Biosensing at Different Molecular Level of Emerging Food Allergens and Adulterants. Biosensors 2020, 10, 10. [CrossRef]

20. Sharma, G.M.; Khuda, S.E.; Parker, C.H.; Eischeid, A.C.; Pereira, M. Detection of allergen markers in food: Analytical methods. In Food Safety: Innovative Analytical Tools for Safety Assessment; Wiley-Blackwell: Hoboken, NJ, USA, 2016; pp. 65-121. ISBN 9781119160588.

21. Nehra, M.; Lettieri, M.; Dilbaghi, N.; Kumar, S. Nano-Biosensing Platforms for Detection of Cow's Milk Allergens: An Overview. Sensors 2020, 20, 32. [CrossRef]

22. Ashley, J.; D'Aurelio, R.; Piekarska, M.; Temblay, J.; Pleasants, M.; Trinh, L.; Rodgers, T.L.; Tothill, I.E. Development of a $\beta$-Lactoglobulin sensor based on SPR for milk allergens detection. Biosensors 2018, 8, 32. [CrossRef] [PubMed]

23. Kuo, T.R.; Chen, W.T.; Liao, H.J.; Yang, Y.H.; Yen, H.C.; Liao, T.W.; Wen, C.Y.; Lee, Y.C.; Chen, C.C.; Wang, D.Y. Improving Hydrogen Evolution Activity of Earth-Abundant Cobalt-Doped Iron Pyrite Catalysts by Surface Modification with Phosphide. Small 2017, 13, 1603356. [CrossRef]

24. Mutalik, C.; Hsiao, Y.C.; Chang, Y.H.; Krisnawati, D.I.; Alimansur, M.; Jazidie, A.; Nuh, M.; Chang, C.C.; Wang, D.Y.; Kuo, T.R. High UV-VIS-NIR light-induced antibacterial activity by heterostructured $\mathrm{TiO}_{2}-\mathrm{FeS}_{2}$ nanocomposites. Int. J. Nanomed. 2020, 15, 8911-8920. [CrossRef]

25. Kuo, T.R.; Liao, H.J.; Chen, Y.T.; Wei, C.Y.; Chang, C.C.; Chen, Y.C.; Chang, Y.H.; Lin, J.C.; Lee, Y.C.; Wen, C.Y.; et al. Correction: Extended visible to near-infrared harvesting of earth-abundant $\mathrm{FeS}_{2}-\mathrm{TiO}_{2}$ heterostructures for highly active photocatalytic hydrogen evolution. Green Chem. 2018, 20, 2663. [CrossRef]

26. Mutalik, C.; Wang, D.Y.; Krisnawati, D.I.; Jazidie, A.; Yougbare, S.; Kuo, T.R. Light-activated heterostructured nanomaterials for antibacterial applications. Nanomaterials 2020, 10, 643. [CrossRef] [PubMed]

27. Yougbaré, S.; Mutalik, C.; Krisnawati, D.I.; Kristanto, H.; Jazidie, A.; Nuh, M.; Cheng, T.M.; Kuo, T.R. Nanomaterials for the Photothermal Killing of Bacteria. Nanomaterials 2020, 10, 1123. [CrossRef]

28. Li, C.H.; Kuo, T.R.; Su, H.J.; Lai, W.Y.; Yang, P.C.; Chen, J.S.; Wang, D.Y.; Wu, Y.C.; Chen, C.C. Fluorescence-guided probes of aptamer-targeted gold nanoparticles with computed tomography imaging accesses for in vivo tumor resection. Sci. Rep. 2015, 5, 15675. [CrossRef]

29. Yougbare, S.; Chang, T.K.; Tan, S.H.; Kuo, J.C.; Hsu, P.H.; Su, C.Y.; Kuo, T.R. Antimicrobial gold nanoclusters: Recent developments and future perspectives. Int. J. Mol. Sci. 2019, 20, 2924. [CrossRef]

30. Chang, T.K.; Cheng, T.M.; Chu, H.L.; Tan, S.H.; Kuo, J.C.; Hsu, P.H.; Su, C.Y.; Chen, H.M.; Lee, C.M.; Kuo, T.R. Metabolic Mechanism Investigation of Antibacterial Active Cysteine-Conjugated Gold Nanoclusters in Escherichia coli. ACS Sustain. Chem. Eng. 2019, 7, 15479-15486. [CrossRef]

31. Palladino, C.; Breiteneder, H. Peanut allergens. Mol. Immunol. 2018, 100, 58-70. [CrossRef] [PubMed]

32. Li, H.; Liang, X.; Zhou, B.; Chen, X.; Hong, Y.; Zhou, R.; Li, S.; Liu, H.; Lu, Q.; Liu, H.; et al. A proteomic analysis of peanut seed at different stages of underground development to understand the changes of seed proteins. PLoS ONE 2020, 15, e0243132. [CrossRef]

33. Hilu, K.W.; Friend, S.A.; Vallanadu, V.; Brown, A.M.; Hollingsworth, L.R.; Bevan, D.R. Molecular evolution of genes encoding allergen proteins in the peanuts genus Arachis: Structural and functional implications. PLoS ONE 2019, 14, e0222440. [CrossRef]

34. Cannon, H.E. The Economic Impact of Peanut Allergies. Am. J. Manag. Care 2018, 24, S428-S433.

35. Meng, S.; Li, J.; Chang, S.; Maleki, S.J. Quantitative and kinetic analyses of peanut allergens as affected by food processing. Food Chem. X 2019, 1, 100004. [CrossRef]

36. Ratnaparkhe, M.B.; Lee, T.H.; Tan, X.; Wang, X.; Li, J.; Kim, C.; Rainville, L.K.; Lemke, C.; Compton, R.O.; Robertson, J.; et al. Comparative and evolutionary analysis of major peanut allergen gene families. Genome Biol. Evol. 2014, 6, 2468-2488. [CrossRef]

37. Zhuang, Y.; Dreskin, S.C. Redefining the major peanut allergens. Immunol. Res. 2013, 55, 125-134. [CrossRef]

38. Kleber-Janke, T.; Crameri, R.; Appenzeller, U.; Schlaak, M.; Becker, W.M. Selective cloning of peanut allergens, including profilin and 2 S albumins, by phage display technology. Int. Arch. Allergy Immunol. 1999, 119, 265-274. [CrossRef]

39. Kulis, M.; Chen, X.; Lew, J.; Wang, Q.; Patel, O.P.; Zhuang, Y. The 2 S albumin allergens of Arachis hypogaea, Ara h 2 and Ara h 6, are the major elicitors of anaphylaxis and can effectively desensitize peanut-allergic mice. Clin. Exp. Allergy 2012, 42, 326-336. [CrossRef]

40. Zhang, W.; Zhu, Q.; Zhang, T.; Cai, Q.; Chen, Q. Thermal processing effects on peanut allergen Ara h 2 allergenicity in mice and its antigenic epitope structure. Food Chem. 2016, 212, 657-662. [CrossRef]

41. Aremu, M.O.; Olonisakin, A.; Bako, D.A.; Madu, P.C. Compositional studies and physicochemical characteristics of cashew nut (Anarcadium occidentale) flour. Pak. J. Nutr. 2006, 5, 328-333. [CrossRef]

42. Aremu, M.O.; Ogunlade, I.; Olonisakin, A. Fatty acid and amino acid composition of protein concentrate from cashew nut (Anarcadium occidentale) grown in Nasarawa State, Nigeria. Pak. J. Nutr. 2007, 6, 419-423. [CrossRef]

43. Ryan, E.; Galvin, K.; O'Connor, T.; Maguire, A.; O'Brien, N. Fatty acid profile, tocopherol, squalene and phytosterol content of brazil, pecan, pine, pistachio and cashew nuts. Int. J. Food Sci. Nutr. 2009, 57, 219-228. [CrossRef] [PubMed] 
44. Breiteneder, H.; Radauer, C. A classification of plant food allergens. J. Allergy Clin. Immunol. 2004, 113, 821-830. [CrossRef] [PubMed]

45. Radauer, C.; Bublin, M.; Wagner, S.; Mari, A.; Breiteneder, H. Allergens are distributed into few protein families and possess a restricted number of biochemical functions. J. Allergy Clin. Immunol. 2008, 121, 847-852. [CrossRef]

46. Burney, P.G.J.; Potts, J.; Kummeling, I.; Mills, E.N.C.; Clausen, M.; Dubakiene, R.; Barreales, L. The prevalence and distribution of food sensitization in European adults. Allergy 2014, 69, 365-371. [CrossRef]

47. Archila, L.D.; Chow, I.-T.; McGinty, J.W.; Renand, A.; Jeong, D.; Robinson, D.; Farrington, M.L.; Kwok, W.W. Ana o 1 and Ana o 2 cashew allergens share cross-reactive CD4+ T-cell epitopes with other tree nuts. Clin. Exp. Allergy 2016, 46, 871-883. [CrossRef]

48. Bastiaan-Net, S.; Pina-Pérez, M.C.; Dekkers, B.J.W.; Westphal, A.H.; America, A.H.P.; Ariëns, R.M.C.; de Jong, N.W.; Wichers, H.J.; Mes, J.J. Identification and in silico bioinformatics analysis of PR10 proteins in cashew nut. Protein Sci. 2020, 29, 1581-1595. [CrossRef]

49. Sicherer, S.H.; Sampson, H.A. Food allergy. J. Allergy Clin. Immunol. 2010, 125 (Suppl. 2), S116-S125. [CrossRef]

50. Crespo, J.F.; Pascual, C.; Burks, A.W.; Helm, R.M.; Esteban, M.M. Frequency of food allergy in a pediatric population from Spain. Pediatr. Allergy Immunol. 1995, 6, 39-43. [CrossRef]

51. Weinberger, T.; Sicherer, S. Current perspectives on tree nut allergy: A review. J. Asthma Allergy 2018, 11, 41-51. [CrossRef]

52. Sicherer, S.H.; Furlong, T.J.; Muñoz-Furlong, A.; Burks, A.W.; Sampson, H.A. A voluntary registry for peanut and tree nut allergy: Characteristics of the first 5149 registrants. J. Allergy Clin. Immunol. 2001, 108, 128-132. [CrossRef]

53. Rukmini, A. Alergi Kacang tanah: Mekanisme, pengujian dan pengendaliannya. J. Ilm. Padma Sri. Kreshna 2009, 1, 1-10.

54. Dubiela, P.; Kabasser, S.; Smargiasso, N.; Geiselhart, S.; Bublin, M.; Hafner, C.; Mazzucchelli, G.; Hoffmann-Sommergruber, K. Jug $\mathrm{r} 6$ is the allergenic vicilin present in walnut responsible for IgE cross-reactivities to other tree nuts and seeds. Sci. Rep. 2018, 8, 11366. [CrossRef] [PubMed]

55. Nugraha, R.; Kamath, S.D.; Johnston, E.; Karnaneedi, S.; Ruethers, T.; Lopata, A.L. Conservation Analysis of B-Cell Allergen Epitopes to Predict Clinical Cross-Reactivity Between Shellfish and Inhalant Invertebrate Allergens. Front. Immunol. 2019, 10, 2676. [CrossRef] [PubMed]

56. Jarupalee, T.; Chatchatee, P.; Komolpis, K.; Suratannon, N.; Roytrakul, S.; Yingchutrakul, Y.; Yimchuen, W.; Butta, P.; Jacquet, A.; Palaga, T. Detecting Allergens From Black Tiger Shrimp Penaeus monodon That Can Bind and Cross-link IgE by ELISA, Western Blot, and a Humanized Rat Basophilic Leukemia Reporter Cell Line RS-ATL8. Allergy Asthma Immunol. Res. 2018, 10, 62-76. [CrossRef]

57. Tong, W.S.; Yuen, A.W.T.; Wai, C.Y.Y.; Leung, N.Y.H.; Chu, K.H.; Leung, P.S.C. Diagnosis of fish and shellfish allergies. J. Asthma Allergy 2018, 11, 247-260. [CrossRef]

58. Li, J.; Li, Z.; Kong, D.; Li, S.; Yu, Y.; Li, H. IgE and IgG4 responses to shrimp allergen tropomyosin and its epitopes in patients from coastal areas of northern China. Mol. Med. Rep. 2020, 22, 371-379. [CrossRef]

59. Abramovitch, J.B.; Kamath, S.; Varese, N.; Zubrinich, C.; Lopata, A.L.; O'Hehir, R.E.; Rolland, J.M. IgE Reactivity of Blue Swimmer Crab (Portunus pelagicus) Tropomyosin, Por p 1, and Other Allergens; Cross-Reactivity with Black Tiger Prawn and Effects of Heating. PLoS ONE 2013, 8, e67487. [CrossRef]

60. Abramovitch, J.B.; Lopata, A.L.; O'Hehir, R.E.; Rolland, J.M. Effect of thermal processing on T cell reactivity of shellfish allergens-Discordance with IgE reactivity. PLoS ONE 2017, 12, e0173549. [CrossRef]

61. Rona, R.J.; Keil, T.; Summers, C.; Gislason, D.; Zuidmeer, L.; Sodergren, E.; Madsen, C. The prevalence of food allergy: A meta-analysis. J. Allergy Clin. Immunol. 2007, 120, 638-646. [CrossRef]

62. Wei-Liang Tan, J.; Valerio, C.; Barnes, E.H.; Turner, P.J.; Van Asperen, P.A.; Kakakios, A.M.; Campbell, D.E. A randomized trial of egg introduction from 4 months of age in infants at risk for egg allergy. J. Allergy Clin. Immunol. 2017, 139, 1621-1628.e8. [CrossRef] [PubMed]

63. Savage, J.H.; Matsui, E.C.; Skripak, J.M.; Wood, R.A. The natural history of egg allergy. J. Allergy Clin. Immunol. 2007, 120, 1413-1417. [CrossRef]

64. Dang, T.D.; Peters, R.L.; Koplin, J.J.; Dharmage, S.C.; Gurrin, L.C.; Ponsonby, A.L.; Martino, D.J.; Neeland, M.; Tang, M.L.K.; Allen, K.J. Egg allergen specific IgE diversity predicts resolution of egg allergy in the population cohort HealthNuts. Allergy Eur. J. Allergy Clin. Immunol. 2019, 74, 318-326. [CrossRef]

65. Peters, R.L.; Koplin, J.J.; Gurrin, L.C.; Dharmage, S.C.; Wake, M.; Ponsonby, A.L.; Tang, M.L.K.; Lowe, A.J.; Matheson, M.; Dwyer, T.; et al. The prevalence of food allergy and other allergic diseases in early childhood in a population-based study: HealthNuts age 4-year follow-up. J. Allergy Clin. Immunol. 2017, 140, 145-153.e8. [CrossRef]

66. Palmer, D.J.; Metcalfe, J.; Makrides, M.; Gold, M.S.; Quinn, P.; West, C.E.; Loh, R.; Prescott, S.L. Early regular egg exposure in infants with eczema: A randomized controlled trial. J. Allergy Clin. Immunol. 2013, 132, 387-392.e1. [CrossRef]

67. de Maat-Bleeker, F.; van Dijk, A.G.; Berrens, L. Allergy to egg yolk possibly induced by sensitization to bird serum antigens. Ann. Allergy 1985, 54, 245-248.

68. Dhanapala, P.; Silva, C.; Doran, T.; Suphioglu, C. Cracking the egg: An insight into egg hypersensitivity. Mol. Immunol. 2015, 66, 375-383. [CrossRef]

69. Anet, J.; Back, J.F.; Baker, R.S.; Barnett, D.; Burley, R.W.; Howden, M.E. Allergens in the white and yolk of hen's egg. A study of IgE binding by egg proteins. Int. Arch. Allergy Appl. Immunol. 1985, 77, 364-371. [CrossRef]

70. Kay, A.B. Allergy and allergic diseases. First of two parts. N. Engl. J. Med. 2001, 344, 30-37. [CrossRef] 
71. Iannotti, L.L.; Lutter, C.K.; Bunn, D.A.; Stewart, C.P. Eggs: The uncracked potential for improving maternal and young child nutrition among the world's poor. Nutr. Rev. 2014, 72, 355-368. [CrossRef]

72. Peters, R.L.; Dharmage, S.C.; Gurrin, L.C.; Koplin, J.J.; Ponsonby, A.L.; Lowe, A.J.; Tang, M.L.K.; Tey, D.; Robinson, M.; Hill, D.; et al. The natural history and clinical predictors of egg allergy in the first 2 years of life: A prospective, population-based cohort study. J. Allergy Clin. Immunol. 2014, 133, 485-491.e6. [CrossRef] [PubMed]

73. Lemon-Mulé, H.; Sampson, H.A.; Sicherer, S.H.; Shreffler, W.G.; Noone, S.; Nowak-Wegrzyn, A. Immunologic changes in children with egg allergy ingesting extensively heated egg. J. Allergy Clin. Immunol. 2008, 122, 977-984. [CrossRef]

74. Kay, A.B. Allergy and Allergic Diseases; Blackwell Science: Malden, MA, USA, 1997; ISBN 9780865428676.

75. Steinman, R.M. The Dendritic Cell System. Annu. Rev. Immunol. 1991, 9, 271-296. [CrossRef] [PubMed]

76. Akdis, M.; Akdis, C.A. Mechanisms of allergen-specific immunotherapy. J. Allergy Clin. Immunol. 2007, 119, 780-789. [CrossRef] [PubMed]

77. Johnson, J.G.; Jenkins, M.K. Co-stimulatory functions of antigen-presenting cells. J. Investig. Dermatol. 1992, 99, S62-S65. [CrossRef]

78. Jabs, F.; Plum, M.; Laursen, N.S.; Jensen, R.K.; Mølgaard, B.; Miehe, M.; Mandolesi, M.; Rauber, M.M.; Pfützner, W.; Jakob, T.; et al. Trapping IgE in a closed conformation by mimicking CD23 binding prevents and disrupts FceRI interaction. Nat. Commun. 2018, 9, 7. [CrossRef]

79. Moreno, J.M.L. Diarrhoea due to allergy to egg: Is there a role for specific IgG? Allergol. Immunopathol. 2014, 42, 177-179. [CrossRef]

80. Ansotegui, I.J.; Melioli, G.; Canonica, G.W.; Gómez, R.M.; Jensen-Jarolim, E.; Ebisawa, M.; Luengo, O.; Caraballo, L.; Passalacqua, G.; Poulsen, L.K.; et al. A WAO_ARIA—GA2LEN consensus document on molecular-based allergy diagnosis (PAMD@): Update 2020. World Allergy Organ. J. 2020, 13, 100091. [CrossRef]

81. Bloom, B.; Cohen, R.A.; Freeman, G. Summary health statistics for U.S. children: National health interview survey, 2010. Vital Health Stat. 10 2011, 250, 1-80.

82. Banchereau, J.; Steinman, R.M. Dendritic cells and the control of immunity. Nature 1998, 392, 245-252. [CrossRef]

83. Pipet, A.; Botturi, K.; Pinot, D.; Vervloet, D.; Magnan, A. Allergen-specific immunotherapy in allergic rhinitis and asthma. Mechanisms and proof of efficacy. Respir. Med. 2009, 103, 800-812. [CrossRef] [PubMed]

84. Kay, A.B.; Bousquet, J.; Holt, P.G.; Kaplan, A.P. Allergy and Allergic Diseases, 2 Volumes, 2nd ed.; Wiley-Blackwell: Hoboken, NJ, USA, 2009; 2184p, ISBN 9781405157209.

85. Mehta, H.; Sicherer, S.H. Food-induced anaphylaxis. Anaphylaxis Princ. Pract. 2013, 32, 83-124. [CrossRef]

86. Volcheck, G.W. Clinical Allergy: Diagnosis and Management; Springer Science \& Business Media: Heidelberg/Berlin, Germany, 2009; 491p.

87. Wood, R.A. New horizons in allergen immunotherapy. JAMA J. Am. Med. Assoc. 2016, 315, 1711-1712. [CrossRef] [PubMed]

88. Pérez-Calderón, R.; Gonzalo-Garijo, M.; Lamilla-Yerga, A.; Mangas-Santos, R.; Moreno-Gastón, I. Recurrent angioedema due to lysozyme allergy. J. Investig. Allergol. Clin. Immunol. 2007, 17, 264-266.

89. Matsui, E.; Eggleston, P. Immunotherapy for Allergic Disease. In Pediatric Allergy: Principles and Practice; Elsevier: London, UK, 2016; pp. 203-209.

90. Juhász, A.; Belova, T.; Florides, C.G.; Maulis, C.; Fischer, I.; Gell, G.; Birinyi, Z.; Ong, J.; Keeble-Gagnère, G.; Maharajan, A.; et al. Genome mapping of seed-borne allergens and immunoresponsive proteins in wheat. Sci. Adv. 2018, 4, eaar8602. [CrossRef] [PubMed]

91. Pahr, S.; Selb, R.; Weber, M.; Focke-Tejkl, M.; Hofer, G.; Dordić, A.; Keller, W.; Papadopoulos, N.G.; Giavi, S.; Mäkelä, M.; et al. Biochemical, biophysical and IgE-epitope characterization of the wheat food allergen, Tri a 37. PLoS ONE 2014, 9, e111483. [CrossRef] [PubMed]

92. Frigerio, J.; Pellesi, R.; Mezzasalma, V.; De Mattia, F.; Galimberti, A.; Lambertini, F.; Suman, M.; Zanardi, S.; Leporati, A.; Labra, M. Development of a DNA barcoding-like approach to detect mustard allergens in wheat flours. Genes 2019, 10, 234. [CrossRef]

93. Gupta, R.S.; Dyer, A.A.; Jain, N.; Greenhawt, M.J. Childhood Food Allergies: Current Diagnosis, Treatment, and Management Strategies. Mayo Clin. Proc. 2013, 88, 512-526. [CrossRef]

94. Nagaharu, U. Genome Analysis in Brassica with Special Reference to the Experimental Formation of B. Napus and Peculiar Mode of Fertilization. Jpn. J. Bot. 1935, 7, 389-452.

95. Kalunke, R.M.; Tundo, S.; Sestili, F.; Camerlengo, F.; Lafiandra, D.; Lupi, R.; Larré, C.; Denery-Papini, S.; Islam, S.; Ma, W.; et al. Reduction of Allergenic Potential in Bread Wheat RNAi Transgenic Lines Silenced for CM3, CM16 and 0.28 ATI Genes. Int. J. Mol. Sci. 2020, 21, 5817. [CrossRef] [PubMed] 